\title{
BDI-uddannelser på højt niveau
}

\author{
Alfred Gynther Christensen
}

Kravet til bibliotekarer og deres kollegaer indenfor BDI-området verden over er steget - eller ændret alt afhængig af, hvordan man ser på det -, og det som følge af samfundsudviklingen: en gennemsnitlig mere veluddannet befolkning, informationseksplosionen, den ny informationsteknologis udvikling m.v. Det smitter naturlig nok også af på BDIuddannelserne, men den politiske vilje er ikke den samme alle steder og uddannelsessystemerne er i forvejen vidt forskellige fra land til land, så der er stor uensartethed mht. hvilken retning udviklingen hidtil er gået $\mathrm{i}$ de enkelte lande når talen er om struktur og indhold af deres BDI-uddannelsesprogrammer.

I artiklen her undersøger jeg, hvad der er kendetegnende for BDI-uddannelserne på, hvad kaldes post-tertiary niveau (kandidatniveau), i de lande, som har de mest avancerede programmer. Vægten er lagt på hovedtendenserne, som jeg ser dem, vurderet ud fra informationsmateriale rekvireret fra udvalgte BDI-uddannelsesinstitutioner i de pågældende lande samt anden beskrivende og analyserende litteratur. Enkelte steder har jeg endvidere givet plads til beskrivelse af mere unikke programmer, hvor de for mig synes at pege på nye mulige udviklingstendenser.

Jeg foretager løbende sammenligninger landene imellem, hvad angår opbygning og hovedindhold af sammenlignelige programmer, men giver ingen konkret vurdering af niveauforskelle, da jeg ikke er overbevidst om, at det kan lade sig gøre på baggrund af det materiale, jeg har at vurdere dem ud fra.

Hvor mine oplysninger stammer fra specifikt kildemateriale - brochurer, kataloger, studieplaner m.m. - modtaget fra institutionerne, henvises der med et tal i rund parantes 0 til Appendiks II, hvor man vil kunne se hvilken institution, der er tale om. Tallene i skarp parantes 0 henviser til referencelisten. 


\section{Udvælgelsesprocedure}

\section{Af International Guide to Library and Information} Science [1] fremgår det, at der i 1984 var 52 lande med et eller flere uddannelsesprogrammer indenfor BDI-området på kandidatniveau (se Appendiks I): diplomprogrammer, master's degree programmer, licentiatprogrammer, certifikatprogrammer og doktor-(PhD) programmer. For især doktorprogrammernes vedkommende er der almindeligvis ikke tale om uddannelser bestående af kurser, men om individuelt forskningsarbejde eventuelt med nogle få tilknyttede metodekurser og andre kurser. Denne type programmer har jeg valgt ikke at beskæftige mig med. Jeg beskæftiger mig kun med, hvad på engelsk benævnes "graduate degrees taken by course-work", dvs. kompetencegivende uddannelser på niveau med Danmarks Biblioteksskoles kandidatuddannelse bygget op omkring kursusarbejde.

Siden 1984, hvor International Guide to Library and Information Science's oplysninger stammer fra, er der sket betydelige ændringer rundt omkring også i lande, som ikke er at finde i nævnte kilde. Derfor har jeg også konsulteret andre kilder, inden jeg har foretaget den endelige udvælgelse. Mit ønske har naturligvis været, at koncentrere artiklen om de lande, der på nuværende tidspunkt har de mest avancerede BDI-uddannelser, eller i hvert fald kan siges at repræsentere hovedtendenserne. Jeg beskæftiger mig således primært med uddannelserne i følgende lande:

USA
Canada
Storbritannien
Tyskland
Holland
Frankrig
Finland
Norge
Indien
Australien

Hertil kommer lande, hvor man har rimeligt avancerede uddannelser, som jeg også gerne havde studeret nærmere, ikke mindst ud fra den betragtning, at man her har en noget anden kultur end de øvrige næsten udelukkende vestlige industrilande. Men desværre har det ikke været muligt for mig at skaffe tilstrækkeligt (for mig forståeligt) materiale til at kunne give dem andet end en flygtig omtale. Det drejer sig om:

$$
\begin{aligned}
& \text { Japan } \\
& \text { Kina } \\
& \text { Sovjetunionen }
\end{aligned}
$$

Om lande blandt de øvrige af de førnæunte 52 , som jeg ikke beskæftiger mig med, kan kort siges, at det eksempelvis drejer sig om mindre Commonwealthlande, hvis uddannelser jeg har vurderet til i væsentlig grad at være kopieret efter britiske; arabiske oliestater, som i følge forskellige kilder har "købt" deres uddannelses-programmer andetsteds (USA, Frankrig eller Storbritannien); lande som Italien, Tjekkoslovakiet, Rumænien og Ungarn, der kun har forholdsvis korte uddannelser på nogle få ugers eller måneders varighed samt forskningsprogrammer; og Belgien, hvor uddannelserne $\mathrm{i}$ henholdsvis den flamsktalende og den fransktalende del af landet er vidt forskellige men begge steder snævert rettet mod traditionelt offentligt biblioteksarbejde.

\section{USA}

Jeg har valgt at lade USA være udgangspunktet, eftersom det var her - nærmere betegnet på Columbia College - Melvey Dewey i 1886-87 startede den første institutionsbaserede bibliotekaruddannelse og også senere i begyndelsen af 1890'erne i New York lavede en niveaudeling af uddannelsen bestående af en toårig hovedsaglig praktisk orienteret bacheloruddannelse som kunne udbygges med et ekstra år til en master's degree.

Fra denne begyndelse til den struktur og det indhold Library and Information Science uddannel- 
sen har i dag nu 100 år efter, ligger der en længere udvikling, om hvilken jeg kun vil nævne nogle få milepæle.

I 1936 offentliggjorde Ralph Munn (daværende leder af Carnegie Library i Pittsburgh) en rapport om tendenserne i uddannelsen til biblioteksarbejde på det pågældende tidspunkt, hvori han bl.a. kritiserede uddannelsen for ikke at uddanne biblioteksledere og for at undervise i rutiner i stedet for i principper. Rapporten gav anledning til en del diskussion, men egentlige ændringer sås først for alvor, da the Library School ved University of Denver indførte et nyt 5-årig program i 1947 førende til en Master's Degree of Library Science. Og følgelig anbefalede American Library Association (ALA) allerede i 1948:

- at et sådan master's degree skulle være den grundlæggende professionelle grad, som kunne opnåes indenfor biblioteksområdet mod tidligere en bachelor's degree;

- at uddannelsen skulle være bred og generel;

- at der skulle være mulighed for specialisering

- samt at yderligere avancerede studier skulle kunne føre til en doktorgrad [2].

Dette fører frem til den nuværende strukturering af uddannelsen indenfor Library and Information Science i USA, som bygger på henholdsvis bachelor, master's, certificate og doctor degrees. Af specielt master's programmer findes der en mængde typer med forskelligt og overlappende indhold udbudt af mange af landets universiteter o.l. Den akademiske standard varierer meget fra universitet til universitet. Af de i 1989 ialt 80 universiteter med uddannelser på master's niveau var kun 59 godkendt af ALA. Enkelte stater har slet ingen godkendte uddannelser [3].

\section{Optagelseskriterier}

For at kunne blive optaget på et master's program kræves først og fremmest et bachelor's degree, men ikke nødvendigvis med specialisering indenfor området. Derfor er det i dag også kun de færreste universiteter, der har uddannelser som Bachelor of Librarianship og Bachelor of Science/Art with Library Science minor/major. En bachelor degree giver ikke i sig selv adgang til ansættelse i en professionel stilling som bibliotekar. Hertil kræves en master's degree, men der er diskussion om, hvorvidt dette skal ændres, om der skal laves flere undergraduate uddannelser, om det ikke er "overflødigt" med en master's degree til mange af de stillinger, vi kalder guiv-bibliotekarstillinger $[4,9]$.

Certificate Degree Program in Advanced Studies in Library Science og lignende uddannelser kræver et master's degree samt som oftest også praktisk erfaring på minimum et par år. Ligeledes gælder det doctor-degree uddannelserne, hvoraf der er to typer henholdsvis Doctor of Philosophy (Ph.D.), som er en forskningsgrad, der giver kompetence til forskning og undervisning, og Doctor of Library Science (D.L.S.), som er en professionel grad, dvs. mere praktisk orienteret mod biblioteksproblemer. Forskellen mellem en Certificate Degree og en Doctor Degree ligger hovedsaglig i, at der for gennemførelse af sidstnævnte kræves en større afhandling, hvor førstnævnte kun består i gennemførelse af et givet antal kurser.

Men tilbage til Master's Degree uddannelserne. Foruden en Bachelor's Degree kræves der for optagelse de fleste steder også: Graduate Record Examination (GRE), dvs. en skriftlig prove hvorigennem egnethed for biblioteksarbejde vurderes; 3 anbefalinger fra tidligere undervisere/professorer eller arbejdsgivere; samt at man møder op til en personlig samtale.

En ansøger, der er sluppet igennem alt dette, får tildelt en personlig rådgiver, en såkaldt academic advisor (en fra den faste lærerstab), som har til opgave at rådgive vedkommende $\mathrm{i}$ hele hans/hendes studieforløb og først og fremmest $i$ begyndelsen, hvor hele studieforløbet skal planlægges. 


\section{Opbygning af uddannelser}

Det videregående amerikanske uddannelsessystem er noget forskelligt fra det, vi kender herhjemme. Vejen til en grad går ikke gennem beståelse af afsluttende examiner men gennem opsamling af credits eller credit hours, som er den enhed, hvormed kurser måles, nærmere betegnet det ugentlige timetal et kursus består af. Langt de fleste kurser, som universiteterne udbyder på graduate niveau, er på 3 credit hours, hvilket vil sige, at de består af 3 timers klasseundervisning (eller forelæsning, gruppearbejde, laboratoriearbejde, selvstudier eller praktisk arbejde på et bibliotek el. lign.) per uge i et semester.

En master's degree uddannelse kan følges på enten fuldtids- eller deltidsbasis. Kravet er, at et vist minimum af credits "opsamles", typisk i størrelsesordenen 36 eller 42 eller for enkelte uddannelser 48 credits. Normalt vil en fuldtidsuddannelse på 36 credits (12 kurser) tage et år.

Der er stor forskel på de forskellige universiteters master's degree uddannelser, når det gælder indhold og opbygning. Enkelte steder tilbydes forskellige næsten færdigpakkede specialiseringsretninger, mens de studerende andre steder selv skal sammensætte hele studieforløbet ud fra en vifte af kurser, som udbydes på universiteterne.

Beskrivelsen her er baseret på studier af 15 amerikanske universiteters master's uddannelser (se Appendiks II) af hvilke de 10 (1-10) har Master of Library and Information Science uddannelser der ligner hinanden og er opbygget af henholdsvis obligatoriske og valgfrie kurser. Antallet af obligatoriske kurser varierer mellem 4 og 12. En nærmere undersøgelse af disse giver et fingerpeg om, hvad man anser for væsentlig grundviden for alle studerende.

\section{Obligatoriske kurser}

Tabel 1: Titler på obligatoriske kurser samt deres hyppighed i 10 af de undersøgte universiteters master's of Library and Information Science degree programmer. Kursustitlerne varierer mere end her angivet, idet jeg har samlet en del af dem under én fællestitel, hvor kursusbeskrivelserne har været nogenlunde enslydende. Der kan være mindre overlapninger af indholdet $i$ endnu flere.

4 Philosophical Foundations of Information Transfer

1 Psycology of Information Use

1 Information in Society

1 Information needs and Analysis

9 Basic Information Sources and Services

3 Societal Function of Library and Info. Systems

7 Information Storage and Retrieval

3 Technology of Information Storage and Retrieval

1 Online Searching and Services

4 Cataloging and Classification

2 Bibliography and Reference

2 Developing Library Collections

3 Library and Information Systems Analysis

8 Library and Information Systems Management

4 Research in Library and Information Systems

2 Technical Services

1 Supervised Field Experience

2 Research Methods

Ikke overraskende viser Tabel 1 , at det først og fremmest er kurser om de grundlæggende informationskilder og -servicer, informationslagring og genfinding samt biblioteks- og informationssystemmanagement, der er obligatoriske. Heller ikke overraskende prioriterer flere også kurser om forskning indenfor biblioteksområdet højt, og tilsvarende gælder det kurser om de filosofiske aspekter ved informationsformidling. Et enkelt sted er feltpraktik svarende til et 3-credits kursus obligatorisk, hvilket ellers er valgfrit de fleste steder.

Foruden obligatoriske kurser har man enkelte steder nogle "anbefalede kurser", som ligger indenfor samme emneområder som de $\mathrm{i}$ tabel 1 
nævnte. Men ellers kan den studerende mere eller mindre frit opbygge sin egen uddannelse, og det er ikke alene ud fra de kurser, som udbydes af Library and Information Science afdelingen, men også kurser $i$ andre af det pågældende universitets afdelinger (dog normalt maximalt 2-3 kurser), - vel at mærke, hvis de har relevans $i$ forhold til vedkommendes studium, dvs. i forhold til det fremtidige karriereønske og iøvrigt svarer til den pågældendes niveau, altså ikke eksempelvis er beregnet for undergraduates.

\section{Valgfrie kurser}

Udbudet af valgfrie kurser indenfor Library and Information Science afdelingerne svinger fra 30 til 50. Altså er det ikke alle steder, der er lige gode specialiseringsmuligheder. Men en række emneområder er generelt dækket ind af et eller flere kurser. Det gælder emner som:

- litteraturen indenfor diverse videnskabsområder

- informationskilder indenfor diverse videnskabsområder

- offentlige publikationer

- design af informationssystemer

- netværkssystemer

- informationsteknologi/microcomputere

- informationsøkonomi

- personaleledelse

- bibliotekshistorie

- bestandsopbygning

- ikke-boglige medier

- boghistorie

- at fortælle eventyr

- skolebibliotek som mediecenter

- børne- og ungdomslitteratur

- voksenlitteratur

- arkivarbejde

- div. specialiseringsområder:

\section{Law Librarianship}

Music Librarianship

Art Librarianship

\section{Map Librarianship}

Et par af disse emner kræver en uddybning:

- Skolebibliotek som mediecenter (School Library Media Center)

Det siger egentlig sig selv, hvad det drejer sig om, men følgende definition uddyber det:

"... the media center, which replaces the old school library... is a learning center in a school where a full range of print and audiovisual media, necessary equipment, and services from media specialists are avaible to students and teachers. " [5 - s.54]

- At fortælle eventyr (Storrytelling)

Følgende kursusbeskrivelse fortæller lidt om, hvad et sådant kursus går ud på:

"Training in storrytelling techniques. Introduction to various genres, such as American Indian tales, Oriental Stories, American tall tales, African and Afro-American stories, and European stories. " 6 s.91]

De fleste universiteter udbyder også kurser under titler som "Individual Studies", "Special Studies" og "Independent Studies", hvor den enkelte selv kan definere og studere sit eget helt specielle emne, hvis emnet ikke dækkes af et af de øvrige kurser. Det kræves dog, at en lærer fra fakultetet kan vejlede vedkommende indenfor området, og normalt skal et sådant selvstudium munde ud i en afhandling.

Endelig er der også de fleste steder benæunt "Thesis", "Dissertation" eller "Research", som heller ikke er egentlige kurser. De ligner de førnævnte individuelle studier - men er af mere videnskabelig karakter - og koncentreret omkring et afhandlingsprojekt. Afhandlingsarbejde er med andre ord ikke noget som almindeligvis kræves for 
at få en master's degree i USA. De studerende vælger selv, om de vil lade dette indgå $i$ deres program svarende til et eller to almindelige kurser.

\section{Specielle uddannelsestyper}

Det vil være muligt at finde særpræg ved alle de undersøgte universiteters programmer, men 5 af dem adskiller sig specielt fra de ovrige 10 . Disse 5 har ikke ret mange fællestræk ud over, at de til forskel fra de øvrige ikke giver de studerende den samme frihed til selv at sammensætte et individuelt studieforløb. Disse 5 universiteter udbyder en række uddannelser med mere eller mindre fastlagt kursusforløb. Jeg har ikke tænkt mig at give en nærmere beskrivelse af de enkelte, men nøjes her med at anføre titlerne på de master's degree uddannelser, de 5 universiteter (11-15) udbyder:

- Academic and Research Librarianship

- Archives Management and Organization

- Bibliographic Control

- Music and Performing Arts Librarianship

- Rare Books and Special Collections

- Law Librarianship

- Health Sciences/Medical Librarianship

- Business/Corporate Librarianship

- Information System Specialist

- Information System Designer

- Information Ressources Mannagement

- The Human Ressource Development/Training Program

$\mathrm{Nu}$ er det som sagt ikke kun på de omtalte 5 universiteter, man kan specialisere sig. De andre steder er det blot op til den enkelte selv at vælge kurserne i forhold til karriereønske. Ved en sammenligning af kursusudbuddet samt kursusbeskrivelserne på de forskellige universiteter får man dog indtryk af, at de ovennæunte specialprogrammer generelt giver en større grad af specialisering, end det er muligt at opnå på de andre universiteter. Her er udbuddet af kurser for det første ikke lige stort inden for alle områder, og for det andet vil man her være afhængig af, om der er efterspørgsel nok på et udbudt kursus. De fleste kurser kræver et vist antal studerende for at blive oprettet.

En uddannelsestype har jeg ikke næunt ovenfor. Denne har jeg valgt at give mere opmærksomhed end de øvrige, ikke mindst fordi over halvdelen af de 15 undersøgte universiteter har en sådan uddannelse, der benæunes:

\section{School Library Media Specialist Program}

Optagelse kræver foruden en bachelor's degree også et undervisningscertifikat, altså dokumentation for at man har evner for at undervise. I opbygning ligner uddannelsen et almindeligt Master of Library and Information Science Degree' program, dog er denne specialuddannelse mere struktureret, dvs. den er lagt i mere faste rammer. De obligatoriske kurser kan eksempelvis hedde:

- Organization and Management of School Libraries/Media Centers (8)

- Design and Production of Instructional Materials (8)

- Libraries, Contemporary Society, and the Adolescent (8)

- Childrens Litterature (2)

- Information Management in Schools (15)

- Work with Children and Young Adults in School and Public Libraries (2)

Også i længden svarer School Library Media Specialist uddannelserne til - i hvert fald de korteste - almindelige master's degree uddannelser på 36 credits, dvs. normalt et år.

Endelig er der også Joint-degree (el. cooperative degree) uddannelser, som kun få universiteter udbyder: 2 af de 15, hvis programmer, jeg har undersøgt.

Joint-degree uddannelserne adskiller sig fra de førnævnte specialuddannelser ved, at de giver de studerende mulighed for at kombinere arbejde 
indenfor 2 fag, dvs. tage 2 universitetsgrader så at sige samtidigt og normalt hurtigere, end hvis de skulle tage dem hver for sig i forlængelse af hinanden. Et eksempel er:

\section{Joint J.D. (Law) - M.S. in Library Science (6)}

Dette giver både en juragrad og en biblioteksvidenskabsgrad, hvilket der ofte kræves til stillinger indenfor Law Libraries. Kursuskravet indenfor biblioteksvidenskabsområdet er her reduceret til 27 credits (mod normal 36). Man får altså en form for "mængderabat".

The Catholic University of America udbyder foruden den nævnte uddannelse følgende Jointdegree uddannelser i samarbejde mellem Library and Information Science afdelingen og afdelingerne indenfor de i paranteser nævnte områder:

Joint M.A. (History) - M.S. in L.S.

Joint M.S. (Biology) - M.S. in L.S.

Joint M.A. (Musicology) - M.S in L.S.

Joint M.A. (English) - M.S. in L.S.

Joint M.A. (Greek and Latin) - M.S. in L.S.

(M.A. = Master of Art, M.S. = Master of Science, L.S. = Library Science)

University of Pittsburgh har også en speciel uddannelse, som kan medregnes her:

\section{Agricultural Information Specialist Program}

Hovedparten af de amerikanske universiteter synes umiddelbart set at give de studerende særdeles frie og temmelig brede rammer til at kunne sammensætte et studieforløb ud fra helt personlige interesser og fremtidige karriereønsker. Men kun umiddelbart set, for det første fordi der er mange obligatoriske kurser. For det andet kræver en stor del af de valgfrie kurser en eller flere prerequisites, dvs. kurser, som skal være gennemført før påbegyndelsen af det pågældende kursus. For det tredje skal et studieforløb godkendes af en fra fakultetet, den personlige vejleder. Og for det fjerde kræves der som sagt et vist antal studerende for at et kursus oprettes. I praksis, tror jeg derfor, at man vil se ret enslydende studieforløb for flere studerendes vedkommende gennem det meste af studiet.

Endelig skal der også betales undervisningshonorar m.v. af egne lommer eller via stipendier, inden man får lov til at studere. Det er forskelligt fra universitet til universitet, både hvordan dette beregnes, og hvor meget det bliver til ialt. Som oftest betales et beløb per semester samt for det antal kurser (credit hours), man følger, hvilket kan virke begrænsende på den måde, at man i hvert fald ikke tager flere kurser end højst nødvendigt.

\section{CANADA}

Der er flere lighedspunkter mellem det amerikanske og det canadiske Library and Information Science uddannelsessystem. Således finder man også de canadiske master's programmer i American Library Assoiciations (ALA) liste over godkendte programmer.

Syv universiteter - heraf et fransksproget - har uddannelser på master's niveau indenfor Library and Information Science.

Det efterfølgende er baseret på beskrivelsen af 3 af universiteternes uddannelser (se Appendiks II), hvilket vil sige 4 uddannelser, da University of Toronto (UT) har to, et Master of Library Science program og et Master of Information Science program. Denne adskildelse af Library Science og Information Science er jeg kun stødt på to andre steder i det nordamerikanske, nemlig på University of Pittsburgh og University of North Carolina at Chapel Hill.

Disse tre canadiske universiteters Master's of Library Science uddannelser er meget lig de tidligere beskrevne Master of Library and Information Science uddannelser i USA, dvs. med samme struktur og tilsvarende kursusudbud. Derimod er deres Master of Information Science uddannelser mere specielle, og af den grund har 
jeg valgt at behandle dem samlet lidt senere. Her skal det først handle om de generelle tendenser i Canada.

Optagelse på en master uddannelse indenfor Library and Information Science kan ske med en bachelor's degree indenfor et hvilket som helst fag. En undersøgelse fra 1983 giver et fingerpeg om, hvordan fordelingen på de forskellige fagområder er i dag. Den viste, at af de 125 studerende, der blev optaget på master's programmet det år på The School of Library and Information Science ved University of Western Ontario havde $45 \%$ en humanistisk uddannelse, $47 \%$ en samfundsvidenskabelig og kun $8 \%$ en naturvidenskabelig baggrund. Samme undersøgelse viste også, at $14 \%$ allerede havde en master's degree, samt at $58 \%$ havde praktisk bibliotekserfaring før optagelse på uddannelsen [7].

En stor del af de canadiske uddannelser varer to år mod kun et år for så godt som alle uddannelser $\mathrm{i}$ USA. De her undersøgte uddannelser er på minimum henholdsvis 45,48 og 54 credits. Emnerne for de obligatoriske kurser er ikke så forskellige fra fra det generelle billede i USA. Det er kurser, der skal give de studerende en introduktion til alle facetter af biblioteks- og informationsområdet og dermed et godt grundlag for deres videre og mere specialiserede studier. En forskel kan imidlertid trækkes frem. Hvor kun 2 ud af 10 amerikanske master's uddannelser har et decideret metodekursus blandt de obligatoriske, har de undersøgte canadiske mindst $e t$ (to af dem har to metodekurser).

Kun et kursus blandt de ca. 150, der ialt udbydes de tre steder, handler om School Libraries (17), hvilket bringer mig frem til at nævne, at man ikke i Canada har en speciel skolebibliotekaruddannelse på højt niveau svarende til School Library Media Specialist uddannelsen i USA. Udannelsen til almindelig skolebibliotekar foregår iøvrigt slet ikke i Library and Information Science afdelingerne men på nogle få universiteters Faculty of Education.
Det øvrige udbud af valgfrie kurser svarer ellers stort set til det generelle billede i USA. Enkelte særegne kan dog nævnes:

- Bilingual Information Systems (16)

- Development Library Services for Multicultural Communities (18)

- Canadiana (Canadisk litteratur, bibliografier, copyright-lov m.v.) (17)

- Canadian Cultural and Communications Policy (16)

På Université de Montréal er undervisningssproget fransk, men uddannelsen Maitrise en bibliothéconomie et des sciences de l'information adskiller sig ellers ikke væsentlig fra de andre universiteters Master's of Library and Information Science programmer [8].

Specielle Master's of Information Science uddannelser i Canada og USA

University of Toronto (UT) er det eneste canadiske universitet, der har et speciel informationsvidenskabs-uddannelse. Af formålsbeskrivelsen for denne ses, hvad den sigter mod at uddanne kandidaterne til:

"Graduates of the program will design and administer databases, design software for information retrieval, design and provide training and customer support for users, market information services and products, and manage information services and systems."

Optagelseskravet er en 4-årig UT-bachelor grad eller tilsvarende fra et andet universitet med bifag i computervidenskab. Uddannelsen varer et år (mod to år for UT's Master's of Library Science program), og består af 4 obligatoriske kurser, mindst 4 valgfrie kurser samt deltagelse $i$ et forskningsprojekt. 
De obligatoriske kurser hedder:

- Origins and Uses of Information for Databases

- Information Retrieval

- Information Services Management

- Research Methods

Det øvrige kursusudbud ligger indenfor det forholdsvis snævre område omkring informationsteknologi: planlægning, design, implementering og brug samt brugeruddannelse.

På University of North Carolina at Chapel Hill findes en indholdsmæssigt set tilsvarende uddannelse, men kravet er her minimum 48 credits (altså vil det tage 2 år). Jeg formoder, at man her kommer lidt dybere ned $i$ de enkelte pensumområder end på University of Toronto.

På University of Pittsburgh er udbudet af kurser i Information Science afdelingen mere end 5 gange større end det, der tilbydes de ovenfor næunte steder, og det vel at mærke indenfor samme emneområde. Mange af dem må derfor nødvendigvis dække meget specifikke emner, hvilket følgende eksempler viser:

- Switching Systems

- Protocols / Interfacing

- Design of Artificial Language

Strukturen af Master of Information Science uddannelsen på University of Pittsburgh er noget unikt derved, at de studerende skal vælge mellem to retninger, henholdsvis Information System Specialist og Information System Designer. De to er bygget op omkring de samme 3 pensumområder: 1)Foundations, 2)Behavioral Science og 3)Systems and Technology. Forskellen mellem dem ligger bl.a. i det antal credits, der kræves indenfor de enkelte områder (ialt 36 credits). Jeg vil ikke gå i nærmere detaljer vedrørende indholdet, men blot fastslå, at Informations System Specialist retningen - ligesom UT's Information Science program - stræber efter at give de studerende specielle færdigheder indenfor udvikling af informations og netværkssystemer fra - som det hedder - konceptualisering til implementering. System Design retningen er mere snævert rettet mod den del af informationsteknologi-udviklingsprocessen, der drejer sig om systemdesign.

Spørgsmålet er, om også andre universiteter vil gå over til at adskille Library Science og Information Science? Det er selvfølgelig svært at spå om fremtiden, men i 1987 blev der lavet en mindre undersøgelse i USA af 45 læreres syn på, hvad der kendetegner en god Master of Library and Information Science uddannelse [9]. Heraf fremgår det, at en stor del fremhævede University of Pittsburgh med deres adskillelse af de to områder som et negativt eksempel, altså ligger det nok ikke mange steder lige for at lade udviklingen gå i den retning. Samme undersøgelse viste dog også, at programmer, der begrænser sig til udelukkende at beskæftige sig med Library Science, heller ikke levnes mange chancer for at overleve i længden.

Det skal tilføjes, at The School of Library and Information Science på University of Pittsburgh er den største af sin art i hele Nordamerika med en lang række avancerede uddannelsesprogrammer, bl.a. også et Master of Science in Telecommunication påbegyndt i 1987 (Master of Information Science programmet startede i 1974).

\section{STORBRITANNIEN}

Den nuværende struktur indenfor biblioteks- og informationsvidenskabsuddannelseri Storbritannien skal ses som et resultat af lokale initiativer. Man har aldrig haft en egentlig national plan på området, hvilket bl.a. afspejler sig i et meget varieret udbud af master's degree uddannelser. Eksempelvis:

- $\quad$ M.Sc. in Information Management (21)

- $\quad$ M.Sc. in Information Studies (21) 
- M.A. in Archives and Records Management (19)

- M.A. in Publishing (19)

- M.A. in School Librarianship (19)

- Master Degree in Librarianship (22)

- Master Degree in Librarianship and Information Studies (22)

En grunduddannelse, der fører til en bachelor's degree, tager 3 år. Enkelte steder kan en sådan udbygges med et ekstra år til en B.A. Honours Degree. På kandidat-niveau har man diploma / master's uddannelser, som også almindeligvis tager et år. Optagelse på disse kræver enten en Bachelor eller en B.A. Honours Degree indenfor et hvilket som helst fag samt normalt også praktisk erfaring af mindst et års varighed på et bibliotek eller i en informationsafdeling af en eller anden art.

En diploma/master's uddannelse indledes med et antal obligatoriske core-courses samt eventuelt enkelte valgfrie kurser. Denne del afsluttes med en eksamen, hvorefter de, som består med et godt resultat - hvis de ønsker det -, kan fortsætte med forberedelsen af en afhandling, som kan fore til en Master's Degree. Studerende som består eksamen, men som ikke ønsker at fortsætte, eller som ikke opnår det, som kræves for master's kandidater, vil blive tildelt et Diploma Degree (22).

Diploma/master's programmer indenfor biblioteksog informationsvidenskab udbydes af såvel universiteter som af polytechnics. Jeg har ikke haft mulighed for at undersøge sidstnævnte institutionstypes uddannelser. Jeg har til gengæld kunnet sammenligne 4 universitetsuddannelser, om hvilket det følgende skal handle.

University of Strathclyde i Glasgow har en Master of Science/Diploma uddannelse indenfor henholdsvis Information Management og Information \& Library Studies, begge varer et år for fuldtidsstuderende. De ni første måneder består af kurser og de sidste tre af afhandlingsarbejde for M.Sc.kandidaternes vedkommende.
De obligatoriske kurser i Information Management uddannelsen beskæftiger sig med planlægning, budgettering og anvendelse af informationsressourser indenfor organisationer, hvilket inkluderer både information i sig selv samt personalemæśsige, financielle og teknologiske aspekter. Det er en uddannelse, der specielt er rettet mod højteknologiske informationsservicevirksomheder i den private sektor.

For kurserne i Information \& Library Studies uddannelsen er hovedemnerne: informationsproduktion og -distribution, informationskilder, informationsteknologi og -systemer, brugerbehov samt ledelse af biblioteks- og informationsafdelinger.

De to programmer peger tydeligvis $\mathrm{i}$ forskellige retninger, mod henholdsvis den private og den offentlige sektor. Mange af de andre universiteters uddannelser inkluderer aspekter fra begge de to områder og er således mere vidtspændende. Michael Brittain (Loughborough University) siger herom:

"The problem is that the curriculum seems to want to be dragged in so many directions at once (...). Unfortunately, it is always easier to see that something should be added to a course than to note a part to be taken away." [11 s. 199]

Han foreslår at programmerne deles op i flere specialiserede områder, eksempelvis i en retning udelukkende dækkende biblioteksaspekter og en anden dækkende informationsvidenskab udenfor biblioteksområdet. Dette er på sin vis, hvad man har gjort på University of Strathclyde, og i hvert fald helt klart det, man har gjort i USA på eksempelvis University of Pittsburgh, hvilket - som jeg tidligere har været inde på - af en del opfattes som en uheldig deling.

En alternativ måde - foreslår Michael Brittain - kan være at lave forskellige kurser således, at nogle er for dem, som kun vil være brugere af informationsteknologier og -systemer og andre er rettet mod dem, som vil være systemdesignere. 
For at spænde over et stadig ekspanderende pensum kunne man også foreslå at udvide uddannelserne til at vare to år, men det afvises ret så klart af Peter Havard-William (Loughborough University):

\begin{abstract}
"A two-year course would bore students to death, because they are looking for a practical orientation and application already in the United Kingdom after a three or four years intensive honours degree and a year's practical experience." [12 - s.94]
\end{abstract}

Om dette er den almindelige holdning, ved jeg ikke.

\section{Aberystwyth's M.Lib. uddannelse}

På University College of Wales, Aberystwyth, har man flere forskellige uddannelser og heriblandt en enkelt "original", et Master's Degree Program in Librarianship (M.Lib.). Kravet for kandidaterne hertil er et diploma degree indenfor Librarianship eller et diploma degree indenfor et andet område samt godkendt praktisk erfaring i biblioteksarbejde. Uddannelsen varer et år, hvilket vil sige, at det faktisk tager to år efter en bachelor eller bachelorhonours degree at få denne master's degree.

Uddannelsen består af syv måneders vejledte studier samt fem måneders afhandlingsarbejde. Der vælges én af seks forskellige retninger, hvoraf temaerne for de fem er defineret på forhånd:1) Design and Evaluation of Information Systems, 2) Library and Information Services for Health Care, 3) The Management of Learning Ressources, 4) The Use of Computers in Libraries and Information Units og 5) Literature and Libraries for Young People.

Hvert af dem består af tre moduler, dvs. studieområder, der på hver sin måde beskæftiger sig med det pågældende tema. For den sjette retning gælder det samme, at den skal bestå af 3 moduler, men her kan de studerende selv vælge modulerne ud fra en række specielle udbud (eksempelvis planlægning af biblioteksbyggeri, personaleledelse og skolebiblioteksarbejde). Der behøver ikke nødvendigvis at være nogen sammenhæng mellem de valgte moduler.

I litteraturen, der beskæftiger sig med uddannelser indenfor biblioteks- og informationsvidenskab, er der forskellige meninger om hvilken vej, der er at anbefale, så det er uvist, om programmerne $\mathrm{i}$ fremtiden vil blive længere, om de vil give generalist- eller specialistkvalifikationer. Et synes man dog at være enige om, nemlig, at de alle konstant bliver "exhorted to do more with less" [13].

Som en lille sidebemærkning og afslutning på omtalen af tendenserne i Storbritanien skal nævnes, at det gennem mine undersøgelser af studieplaner m.v. er faldet mig i øjnene, at man her ikke anvender udtrykket Library "Science" men i stedet Library "Studies". Jeg ved ikke, hvor meget man kan lægge i dette. I USA benyttes Library "science" så godt som på alle universiteter og blev eksempelvis allerede indført på Pratt Institut i New York i 1910, da man ændrede navnet på The School of Library Training til The School of Library Science.

\section{TYSKLAND}

Fra Institut für Bibliothekswissenschaft und Wissenschaftliche Information der Humboldt-Universität $\mathrm{i}$ det tidligere Øst-Berlin lød svaret på min forespørgsel om at få tilsendt informationsmateriale omkring deres undervisningsprogram, at man som følge af forandringerne $i$ landet var ved at forny undervisningsgrundlaget og derfor først ville kunne sende noget til september (1990). Dette er i et brev dateret den 18. juni, og siden er der unægtelig sket betydningsfulde forandringer, så det undrer mig ikke, at jeg ultimo december måned endnu ikke har modtaget noget.

Jeg kan kun gætte mig til, hvad der nu vil ske med de østtyske BDI-undervisningsprogrammer. Sand- 
synligvis vil de udvikle sig under stærkt indflydelse af, dvs. i samme retning som de tilsvarende vesttyske. Der kan også ske det, at nogen af dem vil blive lukket. Det sidste kan eksempelvis tænkes at kunne overgå uddannelsen på Humboldt-Universität eftersom det rent geografisk ligger tæt på Freie Universität Berlin med dets bedre udviklede BDIundervisningsprogrammer.

Det tidligere Østtyskland har ikke haft mange uddannelser på kandidat-niveau. Der har kun været forholdsvis korte videruddannelsesprogrammer og forskningsorienterede forløb førende til en Doctor der Wissenschaften-titel. Efterfølgende er således kun baseret på studier af "vesttyske" institutioners uddannelser og karakteriserer kun de nuværende tendenser i denne del af landet.

Det tyske uddannelsessystem er næsten fuldstændigt forskelligt fra det anglo-amerikanske og forekommer noget kompliceret. På BDI-området gør det det selvfølgelig endnu vanskeligere at danne sig et overblik, at der ej heller i Tyskland er nogen statslige regulativer, at de enkelte forbundsstater har hver deres regler for, hvordan bibliotekspersonalet skal uddannes. Følgelig er der også vidt forskellige institutionstyper inde $\mathrm{i}$ billedet $\mathrm{i}$ denne sammenhæng - også når det gælder undervisning på højt niveau. Her drejer det sig om henholdsvis biblioteksskoler, universiteter og Fachhochschulen. Sidstnævnte kan sammenlignes med de engelske polytecnics, altså polytekniske læreanstalter.

Adgangskravet til alle de her beskrevne uddannelser er en syvsemesters universitetsuddannelse, dvs. en bachelorgrad.

Det er karakteristisk for biblioteksskolerne og Fachhochschulen, at de er meget praktisk orienterede, sådan at forstå, at deres uddannelser næsten fuldstændig peger i retning af eksisterende arbejdsrutiner indenfor specielle typer af BDI-indtitutioner. Dette har i hvert fald været karakteristisk. Jeg vil senere vende tilbage til, at der er sket meget og at der sandsynligvis vil ske flere ændringer på dette punkt.

\section{Biblioteksskolerne}

Biblioteksskolernes uddannelser (Ausbildung für den höheren Dienst an Wissenschaftlichen Bibliotheken) kan i deres målsætning sammenlignes med Danmarks Biblioteksskoles gamle sektion II-uddannelse på den måde, at de sigter direkte på ansættelse indenfor forskningsbiblioteker. Uddannelserne varer to år, heraf et års praktik. Dette gælder i hvert fald for de to, jeg har studeret fra henholdsvis Bibliotheksschule in Frankfurt am Main og Bayerische Bibliotheksschule. De to har endvidere det tilfælles, at kandidaterne ikke må være over henholdsvis 35 og 32 år ved studiernes begyndelse. En tilsvarende aldersbegrænsning har man også på Fachhochschule für Bibliothekswesen Stuttgart.

Hvad angår opbygningen af den teoretiske del har de to nævnte biblioteksskolers uddannelser ikke meget tilfælles.

Bibliotheksschule in Frankfurt am Main's uddannelse er bygget op om syv undervisningsområder (Lehrgebiete), der dækker følgende emner: tysk og udenlandsk biblioteksstruktur (incl. det historiske aspekt), biblioteksbyggeri og -indretning (incl. EDB-implementering), virksomhedsorganisationog publikumsbetjening, management, indexering, boghistorie samt informationssøgning. Hvert emne omfatter 4 - 8 kurser, som spænder over et lidt bredere felt, end det umiddelbart fremgår af titlerne på de nævnte undervisningsområder.

Bayerische Bibliotheksschules uddannelse indledes med en række indføringskurser (Einfuhrungskurse) til de fleste af ialt 22 hovedfagområder, hvoraf 4 er valgfrie. Indholdsmæssigt er uddannelsen meget lig den ovenfor næunte, altså også med focus på emner, der er relevante for ansættelse i ledende stillinger i offentlige videnskabelige biblioteker. Af fag, som er medvirkende til, at Bayerische Bibliotheksschules program synes mere vidtspændende end Bibliotheksschule in Frankfurt am Main's, vil jeg fremhæve: Einführung in das Archivwesen, 
Bibliotheksbetriebslehre (herunder rationalisering, brugerpsykologi m.v.), Recht des Bibliothekswesens og Russisch. Sidstnæunte dækker over transkription, deskriptiv katalogisering og russisk nationalbibliografi.

\section{Fachhochschulen}

På Fachhochschule für Bibliothekswesen Stuttgart (FHB) har man to forskellige men parrallelkørende uddannelser orienteret mod henholdsvis Wissenschaftlischen Bibliothekswesen - altså lig de tidligere nævnte biblioteksskolers uddannelser - og Wissenschaftlischen Dokumentationswesen. Begge varer de 3 år bestående af et års praktik (Großen Praktikum) og en måneds feltpraktik (Kleines Praktikum) samt 23 måneders teoretisk undervisning. Denne struktur er almindelig for Fachhochschule-uddannelser. Studiet starter med de 12 måneders praktik, hvorunder de studerende bl.a. skal vise færdigheder i maskinskrivning (150 anslag/minut). Den teoretiske del består af såvel obligatoriske fag (Plichtfächer) som valgfag, kaldet "uddybende undervisningstilbud" (Vertiefende Lehrangebote). Til de obligatoriske fag hører specielle videnskabsstudier, dvs. studier omkring mindst to videnskabsområder indenfor hvilke den studerende ønsker at "specialisere" sig, eksempelvis jura, ingeniørvidenskab, biologi osv.

Jeg vil koncentrere mig lidt om indholdet af dokumentationsretningen. Timetalsmæssigt er det her følgende undervisningsområder, der ligger højest:

1. Formalindexering

2. Bestands- og informationsformidling

3. Lagerteknik og EDB

4. Bibliografi

5. Virksomhedslære

Et enkelt fag med ekstra højt timetal indenfor fagområdet formalindeksering er Alphabetisierungsreglen (RAK-WB). Fag, som er specielle eller højere prioriteret for dokumentationsretningen end for biblioteksretningen, er: Dokumentationsvæse- nets udvikling, programmeringssprog, statistiske metoder/bibliometri, databanksystemer, databankopbygning samt informationstjenesteydelser i dokumentationsinstitutioner. Der er med andre ord lagt større vægt på anvendelse af de nye informationsteknologier i dokumentalistuddannelsen. Det skal dog hertil siges, at i bibliotekaruddannelsen er emner vedr. informationsteknologien dækket ganske godt ind i forhold til de to først omtalte tyske biblioteksskolers uddannelser. Og det er nok ret karakteristisk, at Fachhochschulen generelt har været hurtigere til at omstille sig og tænke i nye baner end biblioteksskolerne.

Fachhochschule Darmstadt er et sted, hvor der tænkes lidt utraditionelt. Her har man som forsøg oprettet specielle informationsvidenskabsuddannelser, hvor elementer fra informationsvidenskabsuddannelsen kombineres med uddannelse indenfor eksempelvis ingeniørvidenskab, kemi eller biomedicin [14]. På sin vis er det uddannelser lig de tidligere nævnte Joint-degrees uddannelser på The Catholic University of America, dog uden at de tyske kvalificerer til andet end informationsarbejde indenfor de respektive områder.

\section{Freie Universität Berlin}

På Freie Universität Berlin kan man tage informationsvidenskab som hovedfag, bifag eller som tillægsfag, dvs. at man også her på forskellig vis kan kombinere studier indenfor informationsvidenskab med et andet fag i en og samme uddannelse. Et hovedfagstudium er bygget op omkring Grundstudium og Hauptstudium, hvert indeholdende såvel obligatoriske kurser som valgfagsblokke. I grundstudiet vælges to af fire mulige valgfagsblokke, der omhandler grundlag og metoder indenfor:
a) Lingvistik/semiotik/logik
b) Socialvidenskab
c) Historisk/hermeneutisk videnskab
d) Natur- og ingeniørvidenskab 
Nøgleordene for indholdet $\mathrm{i}$ uddannelsen iøvrigt er: informations-/kommunikationsteori, medieteori, vidensorganisation og vidensrepræsentation (herunder videnbaserede systemer og kognitionsforskning), informations-/kommunikationsteknologi, Information Ressource Management, organisationsteori, samfundsmæssige og kulturelle aspekter af informations- og kommunikationsteknologi, informationsøkonomi, kulturteori, informationskultur samt forskningsmetoder.

Gennemgangen her af disse få uddannelser har antydet, at BDI-uddannelsessystemet i Tyskland er noget kompliceret med forbundsstaternes forskellige politikker på området og med forskelligartede institutioner:

"... there is a growing awareness in the $\mathrm{Fe}$ deral Republic of Germany that education and training must be simplified and improved, in view of the fact that European countries are going to move closer to each other. " [15 - s.106]

\section{HOLLAND}

Biblioteksskolerne i Holland er alle i dag tilknyttede regionale polytekniske læreanstalter. Der er seks af slagsen. De har kun 4-årige grunduddannelser. Uddannelser på kandidatniveau indenfor biblioteksog informationsvidenskab findes på henholdsvis Gemeenschappelijhe Opleiding (GO) og Wetenschappelijk Orderwijs (universitetsuddannelse).

Gemeenschappelijke Opleiding (koorperativ oplæring) er en uafhængig institution oprettet i 1950; den udbyder kurser på alle niveauer til ansatte indenfor arkiv-, biblioteks- og informationsområdet. Der er tale om relativt korte deltidskurser, som er meget praksisorienterede, typisk varende 14 måneder med tre dages konfrontationsundervisning per måned, når det gælder kurser på kandidatniveau. De studerende eller deres arbejdsgivere betaler selv for kursusdeltagelsen, således at institutionen kan hvile i sig selv. Kurserne giver et såkaldt GO-diplom, der ikke er officielt anerkendt, men indenfor professionen er det almindeligt anerkendt.[16].

Universitait van Amsterdam er det eneste universitet $\mathrm{i}$ landet, hvor der undervises indenfor området biblioteks- og informationsvidenskab. Her kan studerende indenfor alle fag fra alle landets universiteter følge såkaldte Vrije Onderdelen, hvilket vil sige valgkurser, der dækker emnerne:

A: Bogvidenskab: boghistorie, bogtryk og bogdistribution m.m.

B: Informationsvidenskab:dokumentation, informatik, biblioteksvidenskab, bibliografi, onlinesøgning [17].

En universitets-bachelorgrad samt gennemforelse af nævnte kurser giver adgang til Opleiding Documentaire-Informatikunde (ODI), som er en uddannelse på kandidatniveau. Vrije Onderdelen betragtes $\mathrm{i}$ den henseende som første fase $\mathrm{i}$ et biblioteks-og informationsvidenskabsprogram;men en almindelig biblioteksskoleuddannelse er også adgangsgivende til ODI. I de første tre år, uddannelsen har eksisteret i sin nuværende form - dvs. fra 1987 til 1989 -, har kun 2 af ialt 39 optagne studerende haft en bibliotekaruddannelse bag sig. 16 har haft en humanistisk, 14 en teknisk-naturvidenskabelig og 7 en samfundsvidenskabelig uddannelse.

ODI-uddannelsen er delt op i to moduler:

\section{Ledelse af Informationsservicer}

- omhandler bl.a.: organisationsteori, anvendelse af informationsteknologi, brug og brugere af information, personaleledelse, bestandsstyring, økonomisk planlægning, marketing, undersøgelsesmetoder. 
II. Produktion, vedligeholdelse og brug af information

- omhandler bl.a.: produktion og distribution af information, informationssystemer, klassifikation og indexering, informationskilder (evaluering og brug), bibliografier (produktion og brug).

Oprindeligt startede man med en noget mere ambitiøs uddannelse strækkende sig over to år og bygget op omkring ti moduler, men man har måttet indskrænke det en del - mest af økonomiske årsager - således at uddannelsen i dag kun varer et år. Et af problemerne har været at tiltrække nok studerende til ODI-programmet, hvilket man mener skyldes det forholdsvist høje undervisningsgebyr, der kræves (ca. $34.000 \mathrm{kr}$ ) - resultat af et utilstrækkeligt statstilskud - mere end mangel på interesse for deltagelse i uddannelsen. Dertil kommer at gennemførelse af denne ikke nødvendigvis sikrer arbejde. Arbejdsløshed kender man nemlig også her [16]. Endelig kan det, at man har en form for alternativ i GO-kurserne, også være medvirkende til, at der - i hvert fald fra bibliotekarernes side - ikke er så stor søgning, eftersom de gennem GO-kurserne kan få dækket en del af deres konkrete behov for videruddannelse. Med andre ord er fremtiden for Hollands eneste egentlige uddannelse på kandidatniveau indenfor biblioteksog informationsvidenskab temmelig usikker.

\section{FRANKRIG}

Uddannelse af informationsspecialister i Frankrig - dvs. bibliotekarer, dokumentalister og arkivarer foregår ad flere forskellige ruter, og karakteriseres ved at være mere niveaudelt end det kendes $i$ andre lande. På universiteterne kan man få den første grad allerede efter to år, den næste efter tre, og efter fire års studier en Maitrise, som ikke ligger på niveau med en anglo-amerikansk master's degree, hvad man ellers umiddelbart ville gætte på. Efter endnu et år kan man få enten DEA (Diplome d'Etudes Approfondies), som er første skridt på vej mod en doktorgrad - dvs. en karriere indenfor forskningsområdet -, eller DESS (Diplome d'Etudes Superieures Spécialisées), der sigter mod ledende stillinger indenfor informations- og dokumentationsområdet. Det er disse grader, der bedst kan sammenlignes med en master's degree.

Kandidater som vil følge en uddannelse, der fører til DESS, skal foruden nødvendig teoretisk baggrund $i$ form af en maitrise eller en tilsvarende grad også have en vis praktisk erfaring med informationsbehandling. Den et-årige uddannelse giver mulighed for specialisering indenfor informationsvidenskab, kommunikation, de nye informationsteknologier m.v.

\section{Grandes Ecoles}

Af andre institutioner end universiteterne, der uddanner informationsspecialister, er der en række, der hører ind under kategorien Grandes Ecoles. Jeg vil her omtale de vigtigste, når det drejer sig om uddannelser på kandidatniveau.

Ecole Nationale des Chartes er en særdeles velanset skole, som hovedsaglig uddanner bibliotekarer og arkivarer gennem en fireårig uddannelse efter en toårig universitetsgrad eller lignende [18]. Et kig i studieplanen afslører, at det er en noget speciel uddannelse i forhold til, hvad jeg ellers har haft næsen i. Af obligatoriske kurser kan eksempelvis nævnes: arkæologi, latin, filologi, palæografi, diplomatik (studiet af diplomer o.a.), borgerrettighedshistorie og kanonisk retshistorie (katolsk kirkeret) samt mere kendte så som boghistorie, bibliografi og informatik. Studiet afsluttes med specialearbejde det sidste år, og de studerende tildeles herefter et Diplome d'Archiviste-Paléographe. Trods det at det indholdsmæssigt set er et meget omfattende studium, er det i beskæftigelseshenseende snævert rettet mod meget specielle biblioteks- og arkivfunktioner.

Institut National des Techniques de la Documentation uddanner informationssystemdesignere og information-managers og det via to uddannelser på henholdsvis 12 og 14 måneder. Adgangskravet til 
den første er en maitrise eller lignende, helst en ingeniør-eksamen eller maitrise indenfor økonomi eller jura. Kravene er endvidere, at kandidaterne skal være mindst 26 år, have mindst tre års faglig erhvervserfaring, samt at de gennemfører en skriftlig og en mundtlig optagelsesprøve. Indholdet $i$ uddannelsen er koncentreret om 4 moduler: 1) informationsbehandling, 2)informationssøgning, 3)kommunikation og management samt 4)informatik, telematik og de nye informationsteknologier. Kandidaterne får en grad på niveau med universitetsgraden DESS nemlig Le diplome supérieur des sciences et techniques de l'Information et de la Documentation.

Adgangskravet til den anden uddannelse er en grad (DEA eller tilsvarende) indenfor teknik og naturvidenskab, økonomi eller jura. Indholdet i første semester svarer til førnævnte uddannelse, men i andet semester bliver indholdet mere tekniskmetodisk orienteret, koncentreret omkring emner som strategisk overvågning af information og nye teknologier indenfor informations-servicer (expertsystemer og AI m.v.). Her skal i modsætning til førstnævnte uddannelse laves en afhandling før de studerende kan tildeles Le Mastere specialisé en management de l'Information Strategique.

Hvad angår indhold og længde er der for de to uddannelser paralleller at finde, mest af alt i England. Jeg tænker specielt på University of Stracthclyde's Master of Sciences in Information Management-uddannelse, der for mig at se ligner Le Mastere specialisé en management de l'Information Strategique, et indtryk der ikke mindst kommer af at strategic information management også her står som et af nøgleordene.

The Department of Information Science på University of Stratchclyde er en del af The Stratchclyde Business School. Alene denne oplysning antyder, hvilken vinkel man her uddanner informationsspecialister ud fra, og det er altså en lignende linie, man finder på Institut National des Techniques de la Documentation i Paris.
Institut d'Etudes Politiques de Paris er den sidste, jeg vil medtage af Les Grandes Ecoles. Man har her en etårig uddannelse, der fører til Diplome d'Etudes Superieures Specialisées (DESS) en Information et Documentation, dvs. en uddannelse, der kan sidestilles med DESS på universiteterne. Strukturelt set adskiller den sig imidlertid derved, at der indgår en praktiktidsperiode på tre måneder. Og som det er almindelig for Grandes Ecoles, må ansøgerne igennem en række prøver for at kunne blive optaget. Her drejer det sig om:

- en prøve i korrekturlæsning

- en prove i at give resumé eller sammenfatning af en tekst om almene kulturelle spørgsmål

- en prøve i logik; og

- en prøve i engelsk

Engelsk indgår også som ét af ni fagområder i uddannelsen; i hovedtræk omfatter den sprogets grundstruktur samt indføring i sprogbrug indenfor dokumentation. Jeg har indtryk af, at der ikke er noget specielt ved dette: engelsk (eller eventuelt et andet fremmedsprog) indgår i de franske BDIuddannelser på alle niveauer.

De øvrige fagområder i den omtalte uddannelse er: informatik, lingvistik, matematik, dokumentanalyse, dokumenttyper, indexeringsmetoder, informationssøgning samt management.

Fagområdet matematik beskæftiger sig her med emner som binære relationer, klassifikatoriske hierarkier, kommandorelationer, algebra og elementer af statistik. Det hedder i beskrivelsen, at hensigten er, at de studerende skal få kendskab til et fælles sprog for de eksakte videnskaber, så de kan håndtere og konstruere algoritmer (EDBprogrammer). Det er ikke mange BDI-uddannelser, der sigter mod at give de studerende færdigheder indenfor dette område; men kurser med lignende indhold findes på nogle af de amerikanske universiteter, dog ikke som obligatoriske kurser. 


\section{Tendenser}

Fra forskellig side peges der på problemer og behov for ændringer i det franske uddannelsessystem på BDI-området. Det er som nævnt meget niveaudelt, hvilket vil sige, at de enkelte uddannelser i reglen er meget korte. Problemet er bl.a. at uddannelser på forskelligt indgangsniveau forekommer meget ens $i$ indhold, således at det faktisk kan være svært at skelne det virkelige "output" fra en DESS-uddannelse fra "outputtet" på en DUTuddannelse (Diploma Universitaire de Technologie), der er en toårig grunduddannelse [18].

Mere end $60 \%$ af de studerende på kandidatniveau har en humanistisk eller samfundsvidenskabelig uddannelse og kun $18 \%$ en teknisk-naturvidenskabelig. Fra aftagerside i det private erhvervsliv foretrækkes kandidater med en teknisk-naturvidenskabelig, økonomisk eller juridisk grunduddannelse [19]. Dette modsætningsforhold forsøger man tilsyneladende at rette op på Institut National des Techniques de la Documentation ved at favorisere studerende med baggrund i "de hårde fag" i de adgangsgivende prøver. I studieordningen herfra er der nemlig en notabene-bemærkning, hvor man gør opmærksom på, at kandidaterne med en ingeniøruddannelse eller maitrise indenfor økonomi eller jura automatisk får suppleret deres skriftlige prøve med seks point. Dette svarer til en tiendedel af de points, der skal til for at man har chance for at blive optaget.

Der er iøvrigt ved at ske det, at ingeniørskoler og managementskoler bevæger sig ind på markedet med uddannelsestilbud til informationsspecialister på lederniveau. De kan gå hen og blive en trussel for de traditionelle institutioner på området, hvor vægtningen hidtil generelt set har ligget på grunduddannelser, på udannelse af "biblioteksteknikere" og ikke så meget på uddannelse af "biblioteksledere", dvs. de mere avancerede uddannelser. [19]

\section{FINLAND}

I Finland foregår uddannelsen af bibliotekarer på universiteterne i Tammerfors (Tampere), Åbo (Turki) og Uleåborg (Oulu). Studiestrukturen kan sammenlignes med et dansk universitetsstudium, idet den består af et hovedfag samt et antal bifag, hvor biblioteksvidenskab kan tages som enten hoved- eller bifag. Med andre ord uddannes der såvel bibliotekarer med forskellige biinteresser som forskellige specialister med biblioteks- og informationsvidenskab som biinteresse. Et universitetsstudium af den art tager 5 år.

Jeg har undersøgt, hvad et hovedfagstudium indenfor biblioteks- og informationsvidenskab består af på universiteterne i Tammerfors og Ảbo. På en lang række punkter ligner de hinanden bl.a. derved, at der begge steder indgår et tre-måneders praktiktidsperiode i grunduddannelsen.

I Tammerfors har man et fælles kerneprogram med kurser i følgende overordnede emner:

- biblioteks- og informationsinstitutioner

- informationslagring og -genfinding

- informationsbehov og -søgning

- bibliotekssamlinger

På et senere tidspunkt i studierne vælges to af disse områder for yderligere studier, avancerede studier, hvorefter der afsluttes med en afhandling.

I Ảbo, der er et universitet for den svensktalende del af befolkningen, er kurserne i grundstudiet koncentreret omkring emnerne:

- biblioteksvetenskapensoch informatikens grunder

- metoder för dokumentbehandling och innehållsanalys

- bibliotekens verksamhetsformer

- produktion och användning av litteratur och andra media 
Herefter har man såkaldte fördjupade studier i emnerne:

- biblioteksvetenskaplig forskning - teori och tillämpning

- biblioteksväsendets relationer till vetenskap och kultur: historia, nuläge, framtidsperspektiv.

Sidstnæunte område dækker bl.a. over: idé- og kulturhistoriske udviklingslinier, biblioteksvæsenet, national og kulturel identitet og informationsformidling, minioriteters kultur og informationsformidlingens situation. Også her afsluttes med en afhandling.

Ser man på emnekombinationerne blandt de studerende på Ảbo Akademi, viser der sig de samme tendenser, som i flere andre lande: at biblioteksog informationsvidenskab hyppigst kombineres med humanistiske fag og sjældent med teknisknaturvidenskabelige fag [20].

I nordisk sammenhæng har Finland længe haft de mest indenfor BDI-uddannelser, der her allerede $\mathrm{i}$ begyndelsen af 70'erne fik akademisk status. Og nu har man i såvel Tammerfors som Åbo nye planer om også at indføre en Information Management uddannelse [20] - inspireret af udviklingen i USA og England.

\section{NORGE}

Med en god eksamen fra den treårige grunduddannelse på Statens Bibliotekshøgskole i Oslo og med speciale indenfor informationsvidenskab kan studerende komme ind på en toårig overbygningsuddannelse kaldet Informasjonskunnskap og EDB. Denne uddannelse startede i 1984 med 25 studiepladser fordelt over de to år [21].
Uddannelsen er bygget op om fire studieområder:

1) Hjalpediscipliner: matematik, lingvistik, projektorganisation og specielt programmering.

2) Information og samfund: informationsbegreber, teori, teknologi, automation, økonomi, politik og organisation.

3) Informationsgenfinding: typologi, terminologi, thesauri, dataorganisation, kognitive processer, kunstig intelligens, expertsystemer og evaluering.

4) Databaseteori: typologi, design, data- og filstrukturer, databasesystemer og -evaluering.

Som en del af studiet deltager de studerende i arbejdet med projekter, som Forsknings- og Udviklingsafdelingen på skolen har påtaget sig. Dette varer $\mathrm{i}$ ca. $2 \frac{1}{2}$ måned. Der afsluttes med en afhandling [22].

En forudsætning for, at man kan fortsætte denne overbygningsuddannelse på Statens Bibliotekshøgskole, vil være, at der er nok studerende, og det har man lidt svært ved at få. Problemet er ikke så meget , at der ikke er interesse for uddannelsen, eller at der ikke er udsigt til arbejde bagefter, men derimod at mange ikke kan få fri fra deres nuværende arbejde eller at de ikke har mulighed for at få financieret en sådan uddannelse. En mulig løsning for nogen vil være, hvis de vil kunne følge uddannelsen via korrespondance-kurser, eftersom afstandene i Norge jo i sig selv kan være problemet. Derfor arbejdes der på at kunne tilbyde dette, hvilket i givet fald bl.a. skal foregå ved brug af de nye informationsteknologier (teleteknik).

\section{INDIEN}

Den første Master of Library Science uddannelse i Indien introduceredes på University of Delhi så tidligt som i 1948, og det var selvfølgelig den navnkundige S. R. Ranganathan, der stod bag. 
Hans betydning for uddannelsén af bibliotekarer i Indien har i det hele taget været stor [23].

I dag er det ikke mindre end 39 universiteter, der har en Master of Library and Information Science uddannelse. Adgangskravet til en sådan er en bachelorgrad indenfor Library and Information Science. Her skal tilføjes, at adgangskravet til en Bachelor of Library and Information Scienceuddannelse enten er en bachelor degree med højt gennemsnit eller en master's degree indenfor en hvilken som helst disciplin.

På Panjab University - hvis studieordning er den eneste, jeg har haft mulighed for at studere i detaljer - har man reserverede pladser for specielle grupper af befolkningen, eksempelvis fysisk handikappede, sportsfolk, sønner/døtre/ægtefæller til folk $\mathrm{i}$ forsvaret og faldne militærpersoner, samt efterkommere af dræbte ved terroristangreb i Punjab og Chandigarh provinserne. Forudsætningen er selvfølgelig for disse ligesom alle andre, at de har den nødvendige teoretiske baggrund. Specielt sidstnæunte kategori afspejler en noget uhyggelig side af den virkelighed, man her lever $i$, og tankerne føres uvilkårligt mod de problemer, Indien ikke alene har $\mathrm{i}$ form af etniske og religiøse stridigheder, men også i form af at over halvdelen af befolkningen er analfabeter. At biblioteks- og informationsvidenskab dette til trods er blevet en etableret disciplin, synes imponerende, hvis man ikke ser det i lyset af, at det er et klassedelt samfund, hvor nogle har langt bedre vilkår end andre. Modsat mange andre lande er strukturen og indholdet $\mathrm{i}$ de forskellige indiske universiteters Master's of Library and Information Science uddannelser mere eller mindre ens [24], altså skulle jeg her kunne nøjes med at beskrive Panjab University's uddannelse og samtidigt behandle generelle tendenser.

Varigheden af master studiet er et år, fordelt på de to semestre med følgende kurser:
1. semester:

a) Universe of Knowledge and Research Methodology

b) Information Storage and Retrieval

c) Information Systems and Programmes

d) Library Organization and Administration: Public Libraries, Academic Libraries eller Special Libraries

2. semester:

a) Advanced Classification (Practice)

b) Advanced Cataloguing (Practice)

c) Bibliography and Literature in: Humanities, Natural Sciences, Medical Sciences, Engineering and Technology eller Agricultural Sciences

d) Depth Classification (Theory)

e) Afhandlingsarbejde, eller et af kurserne: Computer Application in Libraries/Information Centers, Operations Research and Systems Analysis eller Education for Library and Information Science (Sociology of and trends in L.I.S. education: national and international levels).

Det fremgår heraf, at der undervejs er nogle valgmuligheder, og det er specielt på det punkt, der kan være forskelle universiteterne imellem. Man har ikke alle steder de samme valgmuligheder. Det bemærkes, at der ikke skal laves en afhandling, idet det ligesom i USA er noget, som kan vælges på linie med nogle kurser.

Det undrer mig lidt, at der er så stor vægtning at klassifikation (UDC og Ranganathans Colon Classification) og katalogisering, når adgangskravèt er en bachelor uddannelse indenfor biblioteks- og informationsvidenskab, hvor netop de fag også har stor vægt (på Panjab University rent faktisk halvdelen af uddannelsens timer).

På University of Madras har man i 1989 som noget helt nyt i Indien startet en toårig uddannelse, hvor adgangskravet er en bachelorgrad indenfor et hvilket som helst fag, og hvor kurser, som dækker emner vedr. den ny teknologi og dens anvendelse, 
er obligatoriske [25]. Dette er dog tilsyneladende uden at fag som klassifikation og katalogisering får en mindre prioritet end eksempelvis på Panjab Universitet. Det første år af studiet er nemlig helliget det "gamle" pensumområde. Problemet hvis man kan kalde det sådan - er det samme, som jeg var inde på under Storbritannien, at man sagtens kan finde noget nyt at tilføje BDI-uddannelserne, mens det at fjerne noget ikke er nær så ligetil.

\section{AUSTRALIEN}

I Australien - som så mange andre steder - har der været en del uenighed blandt lærerne på biblioteksskolerne, og det diskuteres stadigvæk, i hvilken retning bibliotekaruddannelsen skal gå. Man taler i denne forbindelse sågar om to fløje. På den ene side Conservers, der foretrækker en fortsat prioritering af de traditionelle bibliotekariske fag med en langsom naturlig udvikling. Og på den anden side Expansionists, der går ind for mere radikale omvæltninger $\mathrm{i}$ form af nye uddannelser med udvidet indhold også beregnet for kandidater, der er interesserede i informationsbehandling m.v., og som har en bachelor's degree et andet fag end biblioteks- og informationsområdet [25].

I sidste del af firserne er der startet nye uddannelser vedr. Information Science, Information Technology og Information Management. Og på Monash University har man bl.a. en Master of Librarianship uddannelse, der kun er beregnet for kandidater med en bachelor's degree indenfor et andet fag end Librarianship samt praktisk erfaring med biblioteksarbejde. Dette er et toårig fuldtidsstudium med stor vægt på forskning - nærmere betegnet $66 \%$ af studiet. Af øvrige master uddannelser samme steds er der:

\section{- Master of Arts (Librarianship)}

- Master of Arts (Archives and Records)

- Master of Arts (Bibliographical and Textual Studies)
Disse er alle traditionelle uddannelser også i den forstand, at de i hvert fald til dels består af kursusdeltagelse. Det hidtidige mønster i det australske højere uddannelsessystem er ellers, at master's degrees tages by research, altså gennem forskningsarbejde.

Som noget vist nok specielt australsk holdes der på universiteterne ugentlige work-in-progresseminarer, hvor de, der er i gang med eller har afsluttet et forskningsarbejde fremlægger deres resultater dette kan både være undervisere på universiteterne, besøgende udefra og studerende. De studerende, der skriver afhandling forventes at fremlægge deres arbejde på et sådant seminar, som alle studerende iøvrigt "anbefales" at følge regelmæssigt gennem deres studieforløb.

Det er meget få studerende, som folger master uddannelser [26]. Eksempelvis har man på South Australian Institute of Technology kun haft en per år i perioden 1984-1989 og University of Canberra har ialt haft 4 siden 1981 .

Langt større søgning er der til Graduate Diploma uddannelserne som A.C. Foskett (leder af School of Library and Information Management på South Australian Institute of Technology) i et svarbrev på min forespørgsel efter informationsmateriale gør mig opmærksom på, er meget lig de amerikanske Master of Library Science programmer, som han kender en del til, da han har undervist på bl.a. University of California, Los Angeles (UCLA).

Jeg kan her tilføje, at undervisere indenfor BDIområdet $\mathrm{i}$ flere artikler anbefales at søge undervisningserfaring $\mathrm{i}$ andre lande. Mit indtryk er, at engelske og amerikanske undervisere er dem, der hyppigst søger sådanne udfordringer.

Kendetegnende for Graduate Diploma uddannelserne i Australien er, at de er opbygget af obligatoriske og valgfrie kurser og at de normalt tager et år for fuldtidsstuderende. Jeg vil som eksempel give en kort karakteristik af University of Can- 
berras Postgraduate Diploma of Information Studies - ikke fordi det i strukturen kan siges at være typisk, idet der også her er forskelle universiteterne imellem hvad angår antallet og emnerne for de obligatoriske kurser, - men fordi specialiseringsmulighederne er de almindeligst forekommende.

Der indledes her med et metodekursus og et almenorienterende kursus om emner indenfor informationsområdet. De er begge obligatoriske, men herefter vælges der frit alt efter hvilket område, man ønsker at specialisere sig indenfor. Mulighederne er:

- Research and Archival Ressources

- Information and Records Management

- Information Retrieval

- Library Systems and Services

- Services for Young People

Der skal ikke skrives en afhandling, hvilket i det hele taget er almindeligt for diplomprogrammer; men i stedet er der ved denne uddannelse en interessant finesse. De studerende forventes nemlig at skrive en selvstændig artikel til optagelse $\mathrm{i}$ et fagtidsskrift - og det vel at mærke et internationalt tidsskrift - om et emne indenfor deres specialiseringsområde.

\section{JAPAN}

Det er begrænset, hvad der i Japan findes af uddannelser indenfor BDI-området, hvilket $\mathrm{i}$ væsentlig grad skyldes, at myndighederne indtil for nyligt har været af den opfattelse, at bibliotekarisk arbejde var noget enhver med en højere uddannelse umiddelbart ville kunne klare. Men i 1980 fik man et University of Library and Information Science, hvor der holdes etårige specialkurser for studerende med en fireårig universitetsuddannelse [27].

\section{KINA}

BDI-uddannelserne i Kina har hidtil været lokaliseret på nogle få universiteter, hvor man har lagt vægt på humaniora og kulturelle emner. Der arbejdes på at trække uddannelserne over på mere teknisk-naturvidenskabeligeemner. På polytekniske skoler har man nu specielle fireårige grunduddannelser bestående af en kombination af teknisknaturvidenskabelige og biblioteks- og informationsvidenskabelige kurser.

Master's degree uddannelser findes i dag på såvel universiteter som enkelte specielle institutioner, der udelukkende beskæftiger sig med biblioteks- og informationsvidenskabelige uddannelser. Det tager normalt tre år at gennemføre et master's program, der ikke nødvendigvis skal inkludere afhandlingsarbejde $[28,29]$.

\section{SOVJETUNIONEN}

I Sovjetunionen er studerende med en højere uddannelse (eksempelvis en fireårig bibliotekaruddannelse) samt mindst tre års praktisk erfaring kvalificerede til at følge en treårig kandidatuddannelse, under forudsætning af at de består prøver i Kommunistpartiets historie, et fremmedsprog samt et selvvalgt emne. Foruden dette skal alle ansøgerne lave en opgave om et emne indenfor biblioteksarbejde eller bibliografi inden optagelse.

I løbet af kandidatuddannelsen skal de studerende bestå examiner $\mathrm{i}$ henholdsvis: filosofihistorie, et fremmedsprog, pædagogik og et selvvalgt emne, samt fremlægge og forsvare en afhandling.

Under studierne skal de studerende arbejde som forskningsassistenter på kultur-institutioner i byer, hvor de studerer, dvs. i Moskva, Leningrad og Kiev, der er de eneste steder, uddannelsen indtil videre findes [30].

\section{GENERELT}

Undersøgelsen af BDI-studiebeskrivelser har afsløret stor uensartethed, men også ligheder. I det forudgående har jeg forsøgt at tegne dette billede, jeg har fremhævet hovedtendenserne - suppleret 
med detaljer vedrørende specielle og interessante uddannelser - og understreget forskelle og ligheder. Som afslutning vil jeg opsummere nogle af de nævite tendenser samt fremhæve andre generelle karakteristika.

Af de ialt 526 institutioner, der er opgivet i International Guide to Library and Information Science Education (1) og som udbyder BDI-uddannelser på et eller andet niveau, er henved $70 \%$ tilknyttet et universitet eller college, $4 \%$ en polyteknisk læreanstalt eller anden højere uddannelsesinstitution, $7 \%$ et ministerium eller en statslig-, amtslig- eller kommunal myndighed. Og kun $4 \%$ er opgivet som selvstændige institutioner lig Danmarks Biblioteksskole. De resterende er enten tilknyttede en biblioteksorganisation, et nationalbibliotek, en fond, en kulturinstitution (Sovjet) eller andet. Ved en del $(5 \%)$ er der ikke angivet noget om administrativt tilhørsforhold.

Når det gælder institutioner - biblioteksskoler med uddannelser på højt niveau, nyder langt de fleste godt af at være tilknyttet et universitet eller anden højere læreanstalt. En fordel kan det i hvert fald være, hvis - hvilket er almindeligt - BDIstuderende kan tage kurser $\mathrm{i}$ andre afdelinger som en del af eller som supplement til deres uddannelse. Det kan være kurser i EDB, management, økonomi, psykologi osv.

Optagelseskriteriet for de her omtalte uddannelser er normalt en bachelor uddannelse, men dette skal de fleste steder ikke nødvendigvis være indenfor BDI-området. Til gengæld er det almindeligt, at der kræves praktisk erfaring af en vis varighed på et bibliotek eller anden BDI-institution.

Kan der siges noget generelt vedrørende de studerende, der optages på BDI-uddannelserne på post-tertiary niveau? Ja, der er stadig klar kvindedominans, og som det er nævnt flere steder i artiklen, har hovedparten af de studerende en humanistisk eller samfundsvidenskabelig grundud- dannelse. Kun et mindretal har en teknisk-naturvidenskabelig uddannelse bag sig.

Længden af overbygningsuddannelserne er enten et eller to år. Enkelte af de tyske uddannelser tager tre år på fuld tid, men det er inklusive et års praktik. De fleste steder kan uddannelserne tages som både fuldtidsstudium og deltidsstudium.

Strukturen i uddannelserne svinger mellem at bestå af få obligatoriske og mange valgfrie kurser, og til at være "timet" og tilrettelagt hele vejen igennem med kun ganske få valgmuligheder for de studerende.

\section{Sarligt markante uddannelser}

Alene vurderet ud fra indholdsbeskrivelserne findes der også mange variationer blandt BDI-uddannelserne. Alt afhængigt af hvilke interesser man har, vil der være nogle der lyder mere spændende end andre; men skal man udpege dem, der synes at være de mest markante, dem der i særlig grad repræsenterer en bestemt retning, vil der sikkert ikke være den store uenighed.

Jeg er selv tilbøjelig til at falde for de amerikanske og engelske universiteters uddannelser, hvilket dels skyldes, at man her vitterlig har mange uddannelser, der ser ud til at rage op over gennemsnittet, men også fordi, jeg herfra har modtaget professionelt layoutede, farverige kataloger og brochurer, hvor der selvfølgelig heller ikke mangler noget på tekstsiden. Heldigvis har jeg dog også haft en del tidsskriftslitteratur at støtte mig til, så jeg tror ikke, at jeg rammer helt ved siden af, når jeg udpeger følgende institutioner som de mest markante:

School of Library and Information Science på University of Pittsburgh i USA. I deres M.Sc. in Information Science uddannelse stiles der helt klart målrettet mod at uddanne informationsspecialister med færdigheder indenfor det specifikke område, der handler om udvikling og design af informations- og netværkssystemer. Man kan mene, at 
det er et for specialiseret et område inden for biblioteks- og informationsarbejde, men man ved, hvad man går ind til - modsat mange andre steder, hvor pensummet er bredere og målene mere difuse. Jeg vil i det hele taget blandt de amerikanske uddannelser fremhæve de fem $\mathrm{i}$ artiklen omtalte universiteter (11-15) med unikke programmer. De giver indtryk af at føre de studerende gennem et logisk opbygget studieforløb med veldefinerede erhvervsmål. Det er selvfølgelig kun i et land, hvor der er arbejde at få, at man kan tillade sig at være målrettet i så høj grad, som det disse steder er tilfældet. Set med amerikanske øjne - med deres høje idelogiske prioritering af individets ret til at bestemme over sin egen tilværelse så vidt som muligt - vil det nok ikke være de samme universiteter, man vil fremhæve.

Blandt de institutioner, der har udviklet uddannelser med vægt på Information Ressource Management, vil jeg pege på Department of Information Science, der er en del af Strathclyde Business School på University of Strathclyde, som den mest markante. Master of Science in Information Management uddannelsen beskæftiger sig her med planlægning, budgettering og anvendelse af informationsressourcer, eller Strategic Information Management, som det hedder med et nyt udtryk. Hvor University of Pittsburgh uddanner system"designere" og informations"specialister", retter uddannelserne sig her mere mod at uddanne folk, der skal "styre" information.

Det er mit indtryk, at det normalt ligger lidt tungt med kurser vedr. kulturformidling og de samfundsmæssige samt kulturelle aspekter ved informationsteknologien i uddannelserne. Men jeg kan fremhæve Freie Universität Berlin som én undtagelse på det punkt. I deres Informationswissenschaftprogram beskæftiger man sig - foruden med de "traditionelle" kurser i informationsmanagemet, informationsteknologi, visuel kommunikation (interaktiv video) - m.v. også med emner som informationsformidlingens struktur, menneske-, samfunds- og kultur- forståelse samt semiotik. I forhold til de to førnævnte universiteters henholdsvis teknologi- og $ø$ konomifikserede uddannelser er mennesket (informationssøgeren og informationsbrugeren) og informationsformidlingens sociale kontekst mere synlig på Freie Universität Berlin.

\section{Et diskussionsemne}

I tidsskriftslitteraturen diskuteres det en del hvilken retning BDI-uddannelserne skal tage og hvilke fejl og mangler - samt eventuelle styrker - nuværende uddannelser har osv. Man har eksempelvis længe diskuteret om uddannelserne skal være mere metodisk-teoretiske og mindre praktisk orienterede; men for tiden er det $\mathrm{i}$ højere grad spørgsmålet om de nye informationsteknologiers vægt $\mathrm{i}$ uddannelserne, der står i centrum. Følgende citater synes rammende for, hvad diskussionen drejer sig om, og samtidigt repræsenterer de indirekte hovedsynspunkterne:

"... when is a library school a library school or a school of library and information studies and not a low-level school of management or computer application. Where is our field's true substance to be sought?" [26 - s.119]

"... the need for information professionals (is) to be able to manage and use technology as a tool - means to an end, but not an end itself." [31-s.28]

Ved at undersøge studiebeskrivelse fra specielt amerikanske universiteter, får man indtryk af, at der her stilles virkelig store krav til de studerende. Der findes et hav af sophisticatede "mode"kurser om eksempelvis expertsystemer, pc-programmering og managementkurser af både den ene og den anden slags. Man kan have mistanke om, at nogle af disse udbydes med det primære formál at tiltrække de eftertragtede studerende med teknisknaturvidenskabelige interesser. 


\section{Kandidatuddannelsen i Biblioteks- og Infor- ationsvidenskab ved Danmarks Biblioteksskole.}

Artiklen her og undersøgelsen, der ligger bag, er på sin vis udsprunget af, at Danmarks Biblioteksskole nu har fået en Kandidatuddannelse i Biblioteks- og Informationsvidenskab. Det vil være naturligt også at forsøge at placere denne i det brede spektrum af BDI-uddannelser, jeg har omtalt.

Jeg vil lige sige, at jeg ikke har noget nærtgående kendskab til overbygningsuddannelsen eller OBU, som kandidatuddannelsen hedder i daglig tale, udover hvad jeg har kunnet læse mig til i informationsmaterialet, der er blevet offentliggjort herom. Men da det er samme betingelse, jeg har haft hele vejen igennem i denne undersøgelse, vil jeg kunne give den samme behandling som de ovrige uddannelser.

Kort skitseret så har man valgt at lade overbygningsuddannelsen strække sig over to år med fire semestre, som hvert udgør en afsluttet enhed, dvs. med eksaminer. Hovedtemaerne for de enkelte semestre er:

\section{Informationsvidenskab}

2. Informationsforvaltning og -økonomi

3. Anvendt informationsvidenskab

4. Specialesemester

I de første semestre indgår sammenlagt syv obligatoriske kurser, samt et par indtil videre uspecifiserede kurser af "valgfri karakter" (40). Ved et blik på de obligatoriske kurser vil man bemærke, at uddannelsen er meget metodisk orienteret; to kurser omhandler henholdsvis forskningsmetode og forskningsmetodologi. Ellers spænder kurserne informationsformidlingsteori, informationsbehovsanalyse, økonomisk styring, markedsføring, designprocesser, indekseringssprog, genfindingssystemer, brugeruddannelse m.v.
Hvad er det så, man med dette indhold vil uddanne kandidaterne til? For at holde mig til den tidligere anvendte terminologi vil jeg primær sige information "managers", altså lidt i retning af uddannelsen på University of Strathclyde, men OBU-uddannelsen peger også i retning af mere forskningsog udviklingsrettede opgaver.

Men kandidatuddannelsen ved Danmarks Biblioteksskole er stadigvæk ung og har vel endnu ikke helt fundet sit ståsted. Den skal selvfølgelig ikke heller ikke på længere sigt stædig holde sig, hvor den er. Som alle andre uddannelser må den løbende "justeres" i forhold til tidens krav. Et tidsaktuelt spørgsmål er eksempelvis, om BDI-uddannelserne indenfor EF skal harmoniseres i forhold til hinanden.

"Must we harmonize at all and if yes, what
should we harmonize? (...) ... shold we try to
harmonize the curricula to have one kind of
european information specialist or is it better
to leave it as it is and to find all the chances
in the wide range of information field." (prof.
Blumendorf, Tyskland)[32-s.419]

BDI-uddannelser skal være rettet mod markedets behov, hvad enten det nu er et nationalt eller et "indre marked". Men de skal også gerne tilgodese de studerendes specielle ønsker - hvor urealistiske de umiddelbart end måtte lyde set $\mathrm{i}$ forhold til markedets behov, ... synes jeg! 


\section{APPENDIKS I:}

Lande med BDI-uddannelser på post-tertiary niveau i 1984:

$\begin{array}{clll}1 & \text { Albanien } & 5 \text { Kina } \\ 2 & \text { Argentina } & 4 \text { Korea (rep. of) } \\ 32 & \text { Australien * } & 1 \text { Luxemborg } \\ 2 & \text { Belgien } & 1 \text { Malaysia * } \\ 1 & \text { Botswana * } & 1 \text { Marokko } \\ 3 & \text { Brasilien } & 2 \text { Mexico } \\ 12 & \text { Canada * } & 1 \text { New Zealand * } \\ 1 & \text { Costa Rica } & 4 \text { Nigeria * } \\ 1 & \text { Cuba } & 3 \text { Pakistan } \\ 1 & \text { Danmark } & \text { 10 Polen } \\ 4 & \text { Egypten } & 1 \text { Porto Rico } \\ 7 & \text { Filipinerne } & 1 \text { Rumænien } \\ 4 & \text { Finland } & 2 \text { Saudi Arabien } \\ 7 & \text { Frankrig } & 1 \text { Spanien } \\ 3 & \text { Holland } & 1 \text { Sri Lnaka * } \\ 1 & \text { Hong Kong * } & 45 \text { Storbritannien } \\ 23 & \text { Indien * } & 30 \text { Syd Afrika } \\ 1 & \text { Indonesien } & 2 \text { Thailand } \\ 3 & \text { Iran } & 2 \text { Tjekkoslovakiet } \\ 1 & \text { Iraq } & 4 \text { Tyrkiet } \\ 2 & \text { Irland * } & \text { 11 Tyskland (Ø.: 2) } \\ 4 & \text { Israel } & 1 \text { Uganda * } \\ 3 & \text { Italien } & 2 \text { Ungarn } \\ 2 & \text { Jamaica * } & 70 \text { USA } \\ 5 & \text { Japan } & 3 \text { USSR } \\ 3 & \text { Jordan } & 1 \text { Østrig }\end{array}$

Lande der har fået BDI-uddannelser på posttertiary niveau efter 1984:

\section{$1 \quad$ Norge}

(Portugal - har et program undervejs)

Tallene angiver antal undervisningsprogrammer på post-tertiary niveau - dvs. på højt niveau.

* Commonwealth lande

Kilde: International Guide to Library and Information Science Education [1].

\section{APPENDIKS II:}

Institutioner hvis BDI-uddannelser er undersøgt (gennem studiebeskrivelser m.v. erhvervet fra de pågældende steder) med henblik på denne artikel.

USA

1. University of California, Los Angeles (UCLA)

2. University of California, Berkeley

3. University of South Florida

4. The Florida State University

5. University of Missouri-Columbia

6. The Catholic University of America

7. The Uni. of North Carolina at Chapal Hill

8. Simmons College - Boston

9. University of Kentucky

10. Emporia State University

11. University of Pittsburgh

12. St. Cloud State University

13. Pratt Institution Info. Science Center, N.Y.

14. Columbia University, N.Y.

15. Syracuse University

CANADA

16. McGill University

17. The University of Western Ontario

18. University of Toronto

\section{STORBRITANIEN}

19. Loughborough University of Technology

20. The University of Sheffield

21. University of Strathclyde (Skotland)

22. The University College of Wales, Aberystwyth

TYSKLAND

23. Freie Universität Berlin

24. Bibliotheksschule in Frankfurt am Main

25. Bayerische Bibliotheksschule

26. Fachhochschule für Bibliothekswesen Stuttgart

HOLLAND

27. Universitait van Amsterdam 


\section{FRANKRIG}

28. Université de Paris VIII

29. Institut National des Techniques de la Documentation

30. Institut d'Etudes Politiques de Paris

31. Ecole Nationale des Chartes

FINLAND

32. University of Tampere

33. Åbo Akademi

NORGE

34. Statens Bibliotekshøgskole

\section{INDIEN}

35. Panjab University

\section{AUSTRALIEN}

36. University of Canberra

37. Monash University

38. The University of New South Wales

39. South Australian Institute of Technology

\section{DANMARK}

40. Danmarks Biblioteksskole

\section{REFERENCER}

1. International Guide to Library and Information Science Education, 1985.

IFLA Publication 32

\section{Education in Library and Information Scien-} ce / Anthony Debons

I: Encyclopedia of Library and Information Science, Vol. 7. - New York, [cop. 1972]. - s. 414 474.

\section{American Library Directory 1989 - 90}

42. udgave. - New York, 1989. - 2.bd.
4. Master's Degree from a Program Accredited by the American Library Association Required/ Jane Robbins

I: Journal of Education for Library and Information Science, Vol. 30, 1990, nr. 3. - s. 206 217.

5. Library Standards / Felix E. Hirsch

I: Encyclopedia of Library and Information Science, Vol. 16. - New York, [cop. 1975]. - s. 43 62.

6. The School of Library and Information Science: 1989 - 1991 Announcements. - Vol. 74, nr. 6. - 1989. - 100 s. - (The Catholic University of America)

7. Career Aspirations of M.L.S. Students: Yes, the Women are as Ambitious as the Men / Roma M. Harris

I: Journal of Education for Library and Information Science, Vol. 27, 1986, nr. 1. - s. 31 - 37.

8. The University of Montreal and FrenchLanguage Library Education / Marcel Lajeuness og Réjean Savard

I: Journal of Education for Library and Information Science, Vol. 29, 1988, nr. 1. - s. 69 - 74.

9. What Constitutes a High-Quality M.L.S. Program? / Mary Biggs og Abraham Bookstein I: Journal of Education for Library and Information Science, Vol. 29, 1988, nr. 1. - s. 28 - 46.

10. The Future of Library and Information Science Education / Herbert S. White

I: Journal of Education for Library and Information Science, Vol.26, 1986, nr.3. - s.174 - 182. 
11. Implications for Education and Training / Michael Brittain

I: Curriculum developments in Information Science to meet the needs of the information industries in the 1990s. - s. 152 - 205.

12. Looking towards the Future: An Overwiew/ Peter Havard-Williams

I: Education for Information, Vol. 5, 1987, nr. 2/3. s.91 - 104 .

13. The Training and Education of Professional Libraries in Great Brittain / Barry Meakin

I: Informationsspezialisten für Europa: Proceedings. - 1989. - s.7 - 16 .

14. Recent German Trends in Information and Documentation Field / Thomas Seeger

I: Education for Information, Vol. 5, 1987, nr. 2/3. - s.169 - 175 .

15. Aspects of Education and Training for Library and Information Professionals in the Federal Republic of Germany / Wolfrudolf Laux I: Libri, Vol.40, 1990, nr. 2. - s.101 - 111.

16. Opleidung Documentaire - Informatiekunde (ODI) / Albert Boekhorst

I: Informationsspezialisten für Europa: Proceedings, 1989. - s.363 - 375 .

17. Short Report on Library and Information Education in Netherlands and Belguim (Flanders) / Jan H.E. van der Starre

I: Libri, Vol.40, 1990, nr.2. - s.158 - 164.

18. Education and Training of Information Professionals in France / Jean Michel

I: Informationsspezialisten für Europa: Proceedings, 1989. - s.38 - 42 .
19. Facts on Education and Training of Information Specialists in France / Hélène Soenen I: Informationsspezialisten für Europa: Proceedings, 1989 , - s.38 - 42 .

20. Några tankar kring utbildningen av bibliotekarier vid Åbo Akademi / Mariam Ginman I: Signum, Vol.21, 1988, nr.8.- s.198 - 200.

21. Utdanning: biblioteksskolens ressourser og oppgaver / Tor Henriksen

I: Bok og Bibliotek, Vol. 53, 1986, nr. 5, s. 228 229.

22. Continuing and Futher Education at Statens Bibliotekshøgskole / Tor Henriksen

I: Scandinavian Public Library Quarterly, Vol. 18, 1985, nr. 4. - s. $80-81$.

23. Library Science Education in Panjab / G.C. Bansal og U.K. Tikku

I: International Library Review, Vol. 20, 1988, nr. 3. - s. $395-403$.

24. Recent Trends in Education for Library and Information Science in South India / P. Gangadhara Rao og B. Ramesh Babu

I: International Library Review, Vol. 22, 1990, nr. 3. - s. $181-192$.

25. The Transformation of Library Education in Australia / S.E. Burges og S.E. Edwards

I: Education for Information, Vol. 8, 1990, nr. 2. -s. $117-138$.

26. The Future of Library Education in Australia - and its past / W. Boyd Rayward

I: The Australian Library Journal, 1989, May

s. $115-123$.

27. Education for Library and Information Science in Japan / Satoru Takeuchi

I: Encyclopedia of Library and Information Science, Vol. 36, [cop. 1983]. - $239-271$. 
28. Current State of Library and Info. Science Development in China / Wendy Lin Hu

I: Journal of Education for Library and Information Science, Vol. 30, 1990, nr. 3. - 183 - 192.

29. Professionel Education for Library and Information Personals in China / Li Weiming

I: International Library Review, Vol. 21, 1989, nr. 2. - s. $263-275$.

30. Library Education and Research in the Soviet Union compared with Scandinavia / Johan L. Olaisen

I: International Library Review, Vol. 19, 1987

- s. 119 - 142.
31. Educating the Future Information Professional / edited by Toni Carbo Bearman

I: Library Hi Tech, Vol. 5, nr. 2, 1987. - s. 27 40 .

\section{Final Panel Discussion}

I: Informationsspezialisten für Europa: proceedings, 1989. - s. 416 - 432. 